\title{
KETERAMPILAN BERPIKIR KRITIS MAHASISWA PENDIDIKAN FISIKA PADA MATERI RANGKAIAN LISTRIK ARUS SEARAH
}

\author{
Erwina Oktavianty ${ }^{1}$, Sudirman $^{2}$ \\ (Program Studi PendidikanFisika FKIP UNTAN)
}

\begin{abstract}
The aim of this study is to describe the critical thinking skills students of physical education PGMIPA-U on material direct current circuits. Methods used in this study is simple descriptive. where all students PGMIPA-U ever get the material in the direction of the electric circuit asrus basic physics II participated in this research. Based on the analysis of the data found that the average critical thinking skills possessed by students of physics education PGMIPA-U on direct current electrical circuit material is $62.98 \%$. We hope this research can be used as evidence of the earliest descriptions of the critical thinking skills that can be used by interested parties.
\end{abstract}

\section{Key Word : Critical Thinking Skill}

\section{A. LATAR BELAKANG}

Pencapaian standar kompetensi yang tercantum dalam kurikulum pembelajaran Fisika saat ini lebih menekankan pada kemampuan bernalar dan berpikir. Keterampilan berpikir analisis induktif dan deduktif dengan menggunakan konsep dan prinsip fisika dapat menjelaskan berbagai peristiwa alam dan menyelesaikan masalah baik secara kualitatif maupun kuantitatif (Depdiknas, 2006). Ini berarti bahwa siswa mampu mengaplikasikan konsepkonsep Fisika dalam persoalan sehari-hari, baik untuk penyelesaian berbagai masalah maupun memahami berbagai produk teknologi. Tujuan tersebut akan tercapai jika lebih melibatkan siswa di dalam proses belaja rmengajar, sehingga siswa dapat menguasai konsep dan memiliki keleluasaan dalam mengembangkan keterampilan berpikirnya.

Mata kuliah fisika dasar merupakan mata kuliah wajib bagi mahasiswa program studi pendidikan fisika FKIP UNTAN dan mata kuliah ini diberikan dalam dua semester yang menjadi prasyarat bagi mata kuliah selanjutnya pada

\footnotetext{
${ }^{1}$ Erwina Oktavianty adalah Dosen Prog. Studi Pendidikan Fisika FKIP Untan

${ }^{2}$ Erwina dan Sudirman : adalah Dosen Prog. Studi Pendidikan Fisika FKIP Untan
} 
program studi pendidikan fisika. Mata kuliah ini dianggap sebagai salah satu mata kuliah yang sulit bagi mahasiswa karena Fisika Dasar membutuhkan matematika yang rumit (AAPT, 2009); materi yang banyak dan membutuhkan kegiatan laboratorium (Sheppard \& Robin, 2009 dan Heller \& Heller, 1999). Walaupun faktanya mata kuliah fisika dasar mendasari pengembangan rekayasa, desain, perencanaan, teknologi dan mempunyai peran penting dalam berbagai disiplin serta mengembangkan daya pikirmanusia.

Keterampilan berpiki rmenjadi penting untuk dikembangkan dalam perkuliahan fisika dasar karena Peraturan Pemerintah nomor 17 tahun 2010 tentang pengelolaan dan penyelenggaraan pendidikan menunjukkan salah satu tujuan dari pendidikan tinggi, yaitu mentransformasikan dan mengembangkan kemampuan mahasiswa, termasuk untuk merancang apa yang akan dilakukan, melaksanakan apa yang sudah direncanakan, memonitor dan mengevalua siapa yang sedang dan sudah dilakukan, sehingga mereka menjadi kritis, kreatif, inovatif, mandiri, percayadiri, dan bertanggungjawab. Keterampilan berpiki rmerupakan suatu aktivitas mental untuk memperoleh pengetahuan. Berdasarkan prosesnya berpikir dapat dikelompokkan ke dalam berpikir dasar dan berpikir kompleks. Proses berpikir kompleks yang disebut berpikir tingkat tinggi mencakup empat macam, yaitu pemecahan masalah, pengambilan keputusan, berpikir kritis dan berpikirkreatif (Costa, 1985).

Berdasarkan hasil pengamatan selama perkuliahan fisika dasar 1, proses belajar mengajar di kelas cenderung bersifat analitis dengan menitik beratkan pada penurunan rumus-rumus fisika melalui analisis matematis. Mahasiswa berusaha menurunkan rumus dan menghapalnya namun kurang memaknai untuk apa dan bagaimana rumus itu digunakan. Metode ceramah dan Tanya jawab merupakan metode yang biasa digunakan oleh dosen dengan urutan menjelaskan, member contoh, bertanya, latihan, dan memberikan tugas. Soalsoal lebih menekankan manipulasi secaramatematis sehingga mahasiswa yang kurang mampu dalam matematika akan merasa sulit untuk belajar fisika.

Rangkaian listrik arus searah pada perkuliahan fisika dasar merupakan salah satu materi yang banyak menggunakan persamaan matematis dengan konsep yang abstrak. Hal ini karena pada konsep listrik selalu berkaitan dengan arus dan elektron yang abstrak. Penggalian dan pengenalan konsep yang bias dilakukan pada materi ini antara lain dengan menunjukkan gejala makro saja seperti aliran arus di dalam sebuah rangkaian tertutup, maka sifat mikroskopis dalam teori inimenjadi sangatsulit untuk disajikan dalam eksperimen sederhana di kelas atau laboratorium fisika dasar kecuali menggunakan analogi jalannya air dari tempat tinggi ke tempat rendah.. Selain itu rangkaian arus listrik searah sangat dekat dengan kehidupan sehari hari karena penggunaan berbagai alat eletronik.Tentu saja hal ini akan 
mengakibatkan pengembangan proses berpikir mahasiswa dituntut untuk dapat membayangkan berdasarkan akibat yang ditimbulkan oleh arus. DimanaNational Science Teacher Association (NSTA) menyatakanbahwa guru fisika harus memiliki pengetahuan yang luas dan kuat untuk: (1) memahami hakekat dan peran inkuiri ilmiah dalam fisika serta menggunakan keterampilan-keterampilan dan proses-proses inkuiri; (2) memahami faktafakta fundamental dan konsep-konsep utama dalam fisika; (3) dapat membuat jalinan konseptual dalam disiplin fisika sendiri maupun antar disiplin sains, dan (4) mampu menggunakan pemahaman dan kemampuan ilmiah bila berhadapan denganisu-isu personal dansosial (National Research Council, 2000).

Bertolakdaridasarpemikirantersebut, penelitian ini memiliki nilai strategis untuk mengetahui keterampilan berpikirkritis mahasiswa PGMIPA-U pendidikan fisika setelah perkuliahan fisika dasar II pada materi rangkaian arus searah. Dan menambah wawasan baik bagi dosen maupun mahasiswa di Program Studi Pendidikan Fisika FKIP Untan.

Variabel dalam penelitian ini adalah keterampilan berpikir kritis yang digunakan dalam penelitian ini diadaptasi dari indicator keterampilan berpikir kritis Liliasari (1997), yaitu(1) mengidentifikasi/merumuskan pertanyaan; (2) menjawab pertanyaan mengapa, menjawab pertanyaan tetang alasan utama, menjawab pertanyaan tentang fakta; (3) mengidentifikasi kesimpulan, mengidentifikasi alasan yang dikemukakan, menemukan persamaan dan perbedaan, mengidentifikasi hal yang relevan, merangkum; (4) menyesuaikan dengan sumber, memberikan alasan, kebiasaan berhati-hati; (5) melaporkan berdasarkan pengamatan, melaporkan generalisasi eksperimen, mempertegas pemikiran, mengkondisikan cara yang baik; (6) menginterpretasikan pertanyaan; (7) menggeneralisasi, meneliti; (8) menerapkan prinsip yang dapat diterima, mempertimbangkan alternatif; (9) menentukan strategi terdefinisi, menentukan definisi materi subyek; (10) mengidentifikasi asumsi dari alasan yang tidak dikemukakan, mengkonstruksi pertanyaan; (11) merumuskan masalah, memilih kriteria untuk mempertimbangkan penyelesaian, merumuskan alternatif penyelesaian, menentukan hal yang dilakukan secara tentatif, merangkum dengan mempertimbangkan situasi lalu memutuskan; (12) menggunakan strategi logis. Diharapkan hasil penelitian ini dapat dijadikan bukti tentang deskripsi awal tentang keterampilan berpikir kritis dapat dimanfaatkan oleh berbagai pihak yang berkepentingan seperti guru, mahasiswa dan praktisi pendidikan. 


\section{B. METODE PENELITIAN}

Metode penelitian yang digunakan dalam penelitian ini adalah metode survey dengan analisis data deskriptif karena penelitian ini bertujuan untuk mengetahui keterampilan ketrampilan berpikir kritis mahasiswa PGMIPABI pendidikan fisika FKIP UNTAN. Penelitian ini digunakan jika keadaan yang ingin dijelaskan tersebut berasal dari suatu populasi tanpa mengubungkannya dengan keadaan lain yang juga ditemukan pada populasi tersebut (Azwar, 2003: 52).

Sampel penelitian adalah mahasiswa Program Pendidikan Fisika FKIP Universitas Tanjungpura kelas PGMIPABI tahun ajaran 2012-2013 yang menempuh mata kuliah Fisika Dasar II. Populasi dalam penelitian ini adalah mahasiswa yang sedang menempuh mata kuliah fisika dasar II yang terdiri dari 3 kelas. Teknik sampling yang digunakan adalah purposive sampling. Yaitu pemilihan sampel dengan pertimbangan kelas PGMIPABI. Instrument tes yang digunakan untuk mengevaluasi keterampilan berpikir kritis berbentuk pilihan ganda dengan lima pilihan yang dilaksanakan setelah perkuliahan fisika dasar II tahun ajaran 2012/2013.

\section{HASIL PENELITIAN}

Keterampilan berpikir kritis mahasiswa pendidikan fisika dianalisis secara kualitatif berdasarkan hasil tes keterampilan berpikir kritis dalam bentuk pilihan ganda. Tes dilakukan pada mahasiswa PGMIPA-U program studi pendidikan fisika tahun ajaran 2012 - 2013 yang mengambil mata kuliah Fisika Dasar II sebanyak 35 orang mahasiswa. Adapun langkah-langkah yang digunakan untuk menganalisis keterampilan berpikir kritis mahasiswa PGMIPABI pada materi rangkaian arus listrik searah adalah sebagai berikut:

a. Mengelompokkan jawaban mahasiswa.

b. Membuat tabel jawaban yang mengacu pada 12 indikator keterampilan berpikir kritis menurut Liliasari (2007). Jawaban betul pada tahapan tersebut diberi angka satu dan jawaban salah diberi angka 0 .

c. Membuat Tabel rekapitulasi jumah keterampilan berpikir kritis mahasiswa pada setiap indikator untuk kemudian dibuat rata-ratanya.

Indikator keterampilan berpikir kritis yang digunakan adalah sebagai berikut :

(1) mengidentifikasi/merumuskan pertanyaan;

(2) menjawab pertanyaan mengapa, menjawab pertanyaan tetang alasan utama, menjawab pertanyaan tentang fakta;

(3) mengidentifikasi kesimpulan, mengidentifikasi alasan yang dikemukakan, menemukan persamaan dan perbedaan, mengidentifikasi hal yang relevan, merangkum; 
(4) menyesuaikan dengan sumber, memberikan alasan, kebiasaan berhatihati;

(5) melaporkan berdasarkan pengamatan, melaporkan generalisasi eksperimen, mempertegas pemikiran, mengkondisikan cara yang baik;

(6) menginterpretasikan pertanyaan;

(7) menggeneralisasi, meneliti;

(8) menerapkan prinsip yang dapat diterima, mempertimbangkan alternatif;

(9) menentukan strategi terdefinisi, menentukan definisi materi subyek;

(10) mengidentifikasi asumsi dari alasan yang tidak dikemukakan, mengkonstruksi pertanyaan;

(11) merumuskan masalah, memilih kriteria untuk mempertimbangkan penyelesaian, merumuskan alternatif penyelesaian, menentukan hal yang dilakukan secara tentatif, merangkum dengan mempertimbangkan situasi lalu memutuskan;

(12) menggunakan strategi logis.

Hasil penilaian keterampilan berpikir kritis berupa skor yang kemudian dihitung persentasenya. Berdasarkan perolehan data keterampilan berpikir kritis mahasiswa PGMIPAU pada materi rangkaian arus listrik searah didapatkan rata rata keterampilan berpikir kritis adalah 62,98\%. Dengan distribusi pada masing masing indikator seperti pada gambar di bawah ini

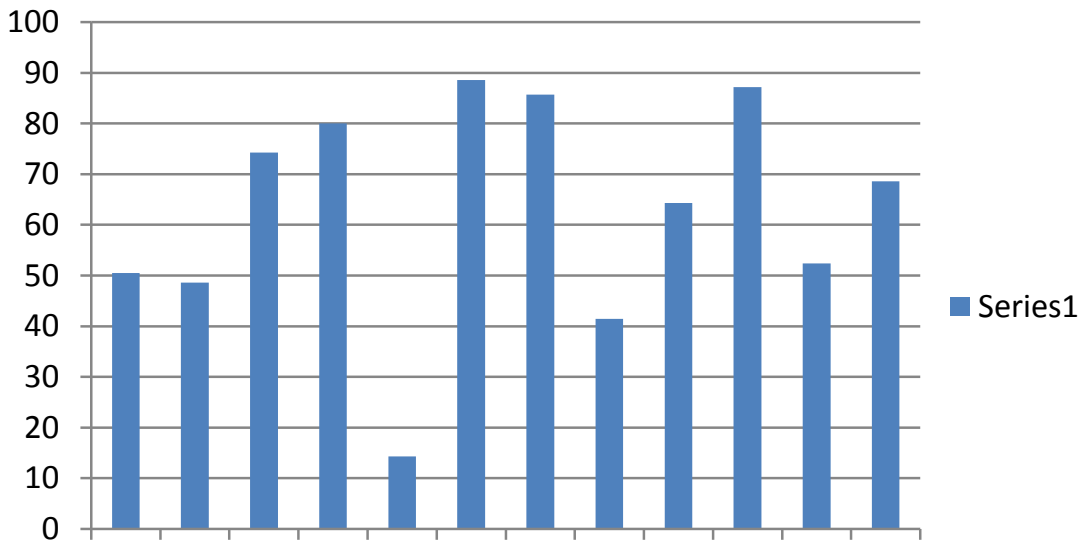

$\begin{array}{llllllllllll}\text { B1 } & \text { B2 } & \text { B3 } & \text { B4 } & \text { B5 } & \text { B6 } & \text { B7 } & \text { B8 } & \text { B9 } & \text { B10 } & \text { B11 } & \text { B12 }\end{array}$

Gambar 4. 1 Perolehan skor keterampilan berpikir kritis pada masing - masing indikator.

Keterangan: (B1) mengidentifikasi/merumuskan pertanyaan, (B2) menjawab pertanyaan mengapa, menjawab pertanyaan tetang alasan utama, menjawab pertanyaan tentang fakta, (B3) mengidentifikasi kesimpulan, mengidentifikasi alasan yang dikemukakan, menemukan persamaan dan perbedaan, 
mengidentifikasi hal yang relevan, merangkum, (B4) menyesuaikan dengan sumber, memberikan alasan, kebiasaan berhati-hati,(B5) melaporkan berdasarkan pengamatan, melaporkan generalisasi eksperimen, mempertegas pemikiran, mengkondisikan cara yang baik, (B6) menginterpretasikan pertanyaan, (B7) menggeneralisasi, meneliti, (B8) menerapkan prinsip yang dapat diterima, mempertimbangkan alternatif, (B9) menentukan strategi terdefinisi, menentukan definisi materi subyek, (B10) mengidentifikasi asumsi dari alasan yang tidak dikemukakan, mengkonstruksi pertanyaan, (B11) merumuskan masalah, memilih kriteria untuk mempertimbangkan penyelesaian, merumuskan alternatif penyelesaian, menentukan hal yang dilakukan secara tentatif, merangkum dengan mempertimbangkan situasi lalu memutuskan, (B12) menggunakan strategi logis.

Grafik diatas menunjukkan bahwa dari 12 indikator yang digunakan untuk menjaring keterampilan berpikir kritis mahasiswa PGMIPABI maka diperoleh data keterampilan berpikir kritis mahasiswa pada masing masing indikator dengan persentase tertinggi pada menginterpretasikan pertanyaan sebesar $88,57 \%$. Persentase terendah adalah pada indikator melaporkan berdasarkan pengamatan, melaporkan generalisasi eksperimen, mempertegas pemikiran, mengkondisikan cara yang baik sebesar 14,29\%. 10 indikator keterampilan berpikir kritis yang lain diperoleh data yang bervariasi yaitu indikator mengidentifikasi/merumuskan pertanyaan sebesar 50,28\% , indikator menjawab pertanyaan mengapa, menjawab pertanyaan tetang alasan utama, menjawab pertanyaan tentang fakta sebesar 48,57\%, indikator mengidentifikasi kesimpulan, mengidentifikasi alasan yang dikemukakan, menemukan persamaan dan perbedaan, mengidentifikasi hal yang relevan, merangkum sebesar $74,29 \%$, indikator menyesuaikan dengan sumber, memberikan alasan, kebiasaan berhati-hati sebesar $80 \%$,indikator menggeneralisasi, meneliti adalah sebesar $85,71 \%$, indikator menerapkan prinsip yang dapat diterima, mempertimbangkan alternatif sebesar $41,43 \%$, indikator menentukan strategi terdefinisi, menentukan definisi materi subyek sebesar $64,29 \%$, indikator mengidentifikasi asumsi dari alasan yang tidak dikemukakan, mengkonstruksi pertanyaan sebesar 87,14 \%, indikator menentukan hal yang dilakukan secara tentatif, merangkum dengan mempertimbangkan situasi lalu memutuskan sebesar 52,38\%, dan indikator menggunakan strategi logis adalah sebesar $68,57 \%$.

\section{PEMBAHASAN}

Dalam penelitian ini, indicator keterampilan berpikirkritis yang diteliti meliputi mengidentifikasi/merumuskan pertanyaan; menjawab pertanyaan mengapa, menjawab pertanyaan tetang alasan utama, menjawab pertanyaan 
tentang fakta; mengidentifikasi kesimpulan, mengidentifikasi alasan yang dikemukakan, menemukan persamaan dan perbedaan, mengidentifikasi hal yang relevan, merangkum; menyesuaikan dengan sumber, memberikan alasan, kebiasaan berhati-hati; melaporkan berdasarkan pengamatan, melaporkan generalisasi eksperimen, mempertegas pemikiran, mengkondisikan cara yang baik;menginterpretasikan pertanyaan; menggeneralisasi, meneliti; menerapkan prinsip yang dapat diterima, mempertimbangkan alternatif; menentukan strategi terdefinisi, menentukan definisi materi subyek; mengidentifikasi asumsi dari alasan yang tidak dikemukakan, mengkonstruksi pertanyaan; merumuskan masalah, memilih kriteria untuk mempertimbangkan penyelesaian, merumuskan alternatif penyelesaian, menentukan hal yang dilakukan secara tentatif, merangkum dengan mempertimbangkan situasi lalu memutuskan; menggunakan strategi logis. (Liliasari,2005).

Perolehan rata - rata skor keterampilan berpikir kritis mahasiswa pgmipau pendidikan fisika adalah 62,98\%. Dengan beberapa indicator berada dibawah persentase $70 \%$. Indikator tersebut adalah melaporkan berdasarkan pengamatan, melaporkan generalisasi eksperimen, mempertegas pemikiran, mengkondisikan cara yang baik sebesar 14,29\%, mengidentifikasi/ merumuskan pertanyaan sebesar $50,28 \%$, indikator menjawab pertanyaan mengapa, menjawab pertanyaan tetang alasan utama, menjawab pertanyaan tentang fakta sebesar 48,57\%, indikator menerapkan prinsip yang dapat diterima, mempertimbangkan alternatif sebesar $41,43 \%$, indikator menentukan strategi terdefinisi, menentukan definisi materi subyek sebesar 64,29\%, indikator menentukan hal yang dilakukan secara tentatif, merangkum dengan mempertimbangkan situasi lalu memutuskan sebesar 52,38\%, dan indikator menggunakan strategi logis adalah sebesar $68,57 \%$.

Hal ini diduga karena kebiasaan mahasiswa dalam menganalisis soal berbentuk perhitungan. Sedangkan keterampilan berpikir kritis berada pada tingkatan kemampuan kognitif menerapkan, menganalisis, mengevaluasi, mensintesa. Indikator paling rendah adalah melaporkan berdasarkan pengamatan, melaporkan generalisasi eksperimen, mempertegas pemikiran, mengkondisikan cara yang baik sebesar $14,29 \%$. Kebiasaan menyelesaikan masalah berdasarkan data pada soal tanpa memberikan tafsiran terhadap data tersebut membuat mahasiswa kesulitan dalam menyelesaikan soal. Indikator ini diwakili oleh dua butir soal yang menyajikan data pengamatan, sehingga mahasiswa diminta untuk menentukan prediksi terhadap data yang diberikan. Perkuliahan fisika dasar II dilaksanakan dengan perkuliahan teori dan praktikum secara terpisah. 
Keterampilan berpikir kritis termasuk salah satu keterampilan berpikir tingkat tinggi. Keterampilan berpikir kritis secara essensial merupakan ketermpilan menyelesaikan masalah (problem solving). Menurut Ennis dalam berpikir kritis adalah kemampuan bernalar dan berpikir reflektif yang diarahkan untuk memutuskan hal-hal yang meyakinkan untuk dilakukan (Costa, 1985). Keterampilan berpikir kritis perlu dikembangkan dalam diri siswa karena melalui keterampilan berpikir kritis siswa dapat lebih mudah memahami konsep fisika, rekaakan masalah yang terjadi sehingga dapat memahami dan menyelesaikan masalah dan mampu mengaplikasikan konsep konsep dalam situasi yang berbeda. Namun bukan hal mudah untuk dapat merangsang keterampilan berpikir kritis mahasiswa (Sutarno, 2010).

\section{E. KESIMPULAN}

Berdasarkan hasil penelitian, dapat disimpulkan bahwa keterampilan berpikir kritis mahasiswa PGMIPAU pendidikan fisika pada masing masing indicator adalah keterampilan berpikir kritis mahasiswa pada masing masing indikator dengan menginterpretasikan pertanyaan sebesar 88,57\%. Melaporkan berdasarkan pengamatan, melaporkan generalisasi eksperimen, mempertegas pemikiran, mengkondisikan cara yang baik sebesar 14,29\%. Mengidentifikasi/ merumuskan pertanyaan sebesar 50,28\%, menjawab pertanyaan mengapa, menjawab pertanyaan tetang alasan utama, menjawab pertanyaan tentang fakta sebesar 48,57\%, mengidentifikasi kesimpulan, mengidentifikasi alasan yang dikemukakan, menemukan persamaan dan perbedaan, mengidentifikasi hal yang relevan, merangkum sebesar 74,29\%, menyesuaikan dengan sumber, memberikan alasan, kebiasaan berhati-hati sebesar $80 \%$, menggeneralisasi, meneliti adalah sebesar $85,71 \%$, indikator menerapkan prinsip yang dapat diterima, mempertimbangkan alternatif sebesar 41,43\%, menentukan strategi terdefinisi, menentukan definisi materi subyek sebesar 64,29\%, mengidentifikasi asumsi dari alasan yang tidak dikemukakan, mengkonstruksi pertanyaan sebesar $87,14 \%$, menentukan hal yang dilakukan secara tentatif, merangkum dengan mempertimbangkan situasi lalu memutuskan sebesar $52,38 \%$, dan indikator menggunakan strategi logis adalah sebesar $68,57 \%$.

\section{F. DAFTAR PUSTAKA}

AAPT. 2009. Building a stronger foundation in the knowledge and understanding of science, American Association of Physics Teacher.

Amin, M. (1987). Mengajar IPA dengan Menggunakan Metode Discovery dan Inquiry Bagian I. Jakarta : Depdikbud. 
Arifin, Mulyani.et al.(2003). Strategi Belajar Mengajar Kimia. Bandung : Jurusan Pendidikan Kimia FPMIPA UPI.

Costa, A.L. (1985).Goal for Critical Thingking Curriculum. In Costa A.L. (ed). Developing Minds : A. Resource Book for Teaching Thingking. Alexandria : ASCD. 54-57.

Depdiknas.(2006). Kurikulum 2006 StandarKompetensi Mata Pelajaran. Jakarta: Depdiknas

Ennis, Robert H. (1995). Critical Thingking.New York: Prentice-Hall

Filsaime, D. K. (2008). Menguak Rahasia Berfikir Kritis dan Kreatif. Jakarta: PrestasiPustakaraya.

Hake, R. R., (1998), Interactive-Engagement Versus Tradisional Methods : A Six-Thousand Student Survey of Mechanics Tes Data For IntroductoryPhysics Course, Am. J. Phys. 66 (1) 64-74

Kadir, A danTriwahyuni.(2003). Teknologi Informasi. Yogyakarta : Kanisius

Karyadinata, R. (2006). Aplikasi Multimedia Interaktif Dalam Pembelajaran Matematika Sebagai Upaya Mengembangkan Kemampuan Berpikir Matematik Tingkat Tinggi Siswa SMA. Disertasi SPs UPI. Bandung :Tidak diterbitkan.

Liliasari. (2002). Pengembangan Model Pembelajaran Kimia untuk Meningkatkan Strategi Kognitif Mahasiswa Calon Guru dalam Menerapkan Berpikir Konseptual Tingkat Tinggi. Laporan Penelitian Hibah Bersaing IX Perguruan Tinggi Tahun Anggaran 20012002.Bandung : FMIPA UPI.

, (2005). Membangun keterampilan Berpikir Manusia Indonesia melalui Pendidikan IPA. Pidato pengukuhan guru besar tetap dalam ilmu pendidikan IPA. UniversitasPendidikan Indonesia.

National Research Council, 2000.Inquiry and the National Science Education Standards: A Guide for Teaching and Learning.

Ruseffendi. (2005). Dasar-Dasar Penelitian Pendidikan dan Bidang NonEksakta Lainnya. Bandung : Tarsito.

Sheppard, K. \& Robbins, D.M. 2009. The "First Physics First" Movement, 1880-1920. The Physics Teacher, 47, 46-50.

Stiggin, R.J. (1994). Student-Centered Classroom Assessment. New York : Macmillan College Publishing Company, Inc.

Torrance, EP. \& Safter, H.T. (1999). Making the Creative Leap and Beyond. Buffalo, NY: Creative Education Foundation Press. 
Wahyudi, J.B. (1992). Teknologi Informasi dan Produksi Citra Bergerak. Jakarta : PT. Gramedia. 